\title{
Elemental analysis of five selected grasses of sub family Pooideae from University of Peshawar Campus, KP, Pakistan
}

Muhammad Nauman Khan $^{1 *}$, Sajjad Ali ${ }^{1}$, Hina Akram ${ }^{1}$, Farmanullah Jan ${ }^{1}$, Inzimam ul Haq ${ }^{1}$, Syed Mukaram Shah ${ }^{2}$, Muhammad Adnan², Sayyed Muhammad Hanif ${ }^{4}$ and Abu Nasar Siddique ${ }^{5}$

1. Department of Botany, Bacha Khan University, Charsadda-Pakistan

2. Centre of Plant Biodiversity, University of Peshawar-Pakistan

3. Department of Chemistry, Bacha Khan University, Charsadda-Pakistan

4. Department of Botany, University of Peshawar-Pakistan

5. Department of Biotechnology, Bacha Khan University, Charsadda-Pakistan

*Corresponding author's email: nomiflora@uop.edu.pk

Citation

Muhammad Nauman Khan, Sajjad Ali1, Hina Akram, Farmanullah Jan, Inzimam ul Haq, Syed Mukaram Shah, Muhammad Adnan, Sayyed Muhammad Hanif and Abu Nasar Siddique. Elemental analysis of five selected grasses of sub family Pooideae from University of Peshawar Campus, KP, Pakistan. Pure and Applied Biology. Vol. 8, Issue 2, pp1296-1306. http://dx.doi.org/10.19045/bspab.2019.80072

\begin{tabular}{llll}
\hline \hline Received: 12/01/2019 & Revised: 18/04/2019 & Accepted: 22/04/2019 & Online First: 26/04/2019 \\
\hline \hline
\end{tabular}

\section{Abstract}

Grasses show numerous useful traits as energy crops and have been expanding enthusiasm for their utilization therefore proficient production of energy from such enduring grasses requires the decision of most proper grass species for the natural, climatic and ecological conditions. A comprehensive survey was carried out during 2017-18 from University of Peshawar, Pakistan in blooming and flowering season. Total of five forage species were collected, preserved, identified and examined for its nutritive value as best fodder. A total of 15 nutrients were observed that are essential for all metabolic activities, production of more milk in livestock and major constituents for growth. The macro-micro minerals composition variable from one growth stage to other. All the five species are best source of food supplement for livestock and with respects to elements contents showed that they have a high energy potential as a fodder for livestock. Therefore information on wild grasses regarding their nutritional value and their biological significance must be useful for future use.

Keywords: Forage; Phenological stages; Pooideae; UOP campus

\section{Introduction}

The area is stretched over an average of 1050 acres of land. Altitude of the proposed area is $365 \mathrm{~m}$ above the sea level. It is surrounded by Khyber Teaching Hospital in the south region, Professor Colony in the northern region, BISE Peshawar on the west region and PCSIR on the eastern region. Research area (University of
Peshawar campus) having $33^{\circ} 44 /$ to $34^{\circ} 15 /$ North latitude and $71^{\circ} 22 /$ to $71^{\circ} 42 /$ East longitudes covered about $1257 \mathrm{~km}^{2}$ of the total area with regards to an altitude of 1173 feet above the sea level [1]. The Pooideae is the sub leading family of Poaceae having approximately 4000 taxon and about more than 200 genera. Economically grasses are very important as that contain major crops 
i.e. Zea maize, Pennesetum typhoides, Triticum aestivum, Oryza sativa, Saccharum officinarum, Sorghum bicolor, Cymbopogon citratus, Avena sativa, Hordeum vulgare and some ornamental grasses. Poaceae is the $4^{\text {th }}$ extent spermatophyte family having 11000 species and 800 genera through worldwide and in Pakistan a total of 158 genera and 492 species distributed in different regions (Table 1). Grasses mostly grow in temperate conditions as pastures have been confined and refer as cool season plants [2]. The cool and temperate zone grasses are mostly herbaceous [3]. In the mountainous regions the native forage has the ability of browsing, grazing and nourishment of animals in rangelands, deserts, grassland and in plains [4]. Elemental composition of native grasses provides baseline information in assigning their nutritive value for livestock [5]. A large number of livestock's outcome in over-grazing and over-browsing of natural vegetation and they get fodder, fuel, tubers and other edible parts from forest besides cultivating some seasonal agricultural crops like maize and wheat in small areas [6]. In the north areas of Pakistan the fodder species play a crucial role for contributors to browsing and grazing animal nutrition in the highlands. The following constituents such as crude proteins, moisture contents, crude fibers, ash contents, neutral detergent fiber and minerals, while their average concentration of dry matter and acid detergent fibers both are fewer in quantity as compared to other plants. Warm climate grasses have comparatively more grazing livestock in depend upon forage plants to fulfill their nutrients supplements. In the dry harvesting seasons of crops the farmers traditionally used the fodder plant species for grazing animals. Living organisms on planet mostly depends on cereals like maize, wheat, rice and lemon grass which are considering as major crops used as a need of balanced diet. For exploration of fodder plants its chemical constituents, biological screening, antibacterial activities, cell wall constituents and antioxidant activities of grasses, very little work has been done on these native grasses in different regions of KP, Pakistan [7]. Animal's population confined on many diverse aspects such as improved nutrients, both quantity and quality of forage plants, improved ecosystem, pathogens control and other topographic and edaphic factors. Determination of constituents in the plants should be directed to increase nutrients storage, marketing and processing of food supplements. Cereal crops have total proteins intake is about $65 \%$, while caloric consumption is about $61 \%$ [8]. Hannah and Krishnakumari [9] stated that all the nutrients both micro and macro are essential for the functioning of biochemical reaction inside body of living organisms. Different types of large molecule such as protein, lipids, alkaloids, flavonoids, flavone, flavanone, flavanole, certain terpenoid and some cell wall constituents like acid detergent fiber, neutral detergent fiber, nitrogen free extract and lignin are vital constituents for survival of life. Both quantity and quality of ash contents, carbohydrates, lipids, and protein, cellulose and hemicellulose contents present in different part of plants are essential factor for the assortment of nutritious value, drug plants identification, classification of drugs plants and plant health improvement [10]. Macronutrients maintain the basic framework of different cells, tissues and body organs and imperative to defend the body fluid [11]. Therefore, this work highlighted the mineral status, composition and potentiality of fodder species.

\section{Materials and Methods Site details}

The study was conducted in University of Peshawar campus which are located in district Peshawar with $33^{\circ} 44 /$ to $34^{\circ} 15 /$ North latitude and $71^{\circ} 22 /$ to $71^{\circ} 42 /$ East longitudes covered about $1257 \mathrm{~km}^{2}$ of the total area with regards to an altitude of 1173 feet above the sea level. The area is stretched over an average of 1050 acres of land. Altitude of the proposed area is $365 \mathrm{~m}$ 
above the sea level. Mean annual maximum temperature is $30.4{ }^{\circ} \mathrm{C}$ while mean minimum temperature is $14.9^{\circ} \mathrm{C}$ with mean annual precipitation of $405.8 \mathrm{~mm}$ and relative humidity is $57.7 \%$ [1].

\section{Collection and preservation of grasses samples}

Field survey was conducted during 2017-18 to explore and collect different herbaceous grasses in blooming and flowering seasons. Five herbaceous grasses which belonged to sub family Pooideae were collected in three growth stages (Table 2, Figure 1-15). For nutritional analysis about 3000 grams of each specimen were collected and kept in oven for an hour, grinded into powder and then kept in polythene bags.

\section{Identification of selected grasses}

After proper collection and preservation of grasses, samples were then identified with the help of available literature $[2,12,13]$. The samples were pasted in Herbarium sheets and then submitted to PUH (Peshawar University Herbarium) for other researchers as a future record.

\section{Elemental analysis}

As per protocol of (Model Perkin Elmer AA Analyst 700) the samples were determined by using Atomic Absorption Spectrophotometer at CRL lab, Department of Physics, University of Peshawar (Table 2, Figure 1-15).

\section{Results and discussion}

A comprehensive survey was carried out during 2017-18 in blooming and flowering season in University of Peshawar campus. Total of five herbaceous grasses were collected in three different growth stages which belong to family Poaceae and sub family Pooideae. The results of current study showed that all the observed species has good taste, high minerals and nutritive value and hence proved that grasses has high potential to be utilized as beneficial source for livestock. Different compositions of minerals were detected in all three growth stages. Bromus catharticus has high magnesium contents in all growth stages $(0.25 \%, 0.22 \%$ and $0.17 \%)$ followed by Hordeum murinum $(0.25 \%, 0.14 \%$ and
$0.09 \%)$ while in Alopecurus myosuroides $(0.06 \%)$ magnesium contents is present. Bones and muscle fibers had high magnesium contents in body. Magnesium is mainly responsible for all physiological processes in animals as well as in plants [14]. In Bromus catharticus calcium contents are higher in all condition $(0.35 \%$, $0.25 \%$ and $0.34 \%$ ) followed by Alopecurus $(0.14 \%$ and $0.10 \%)$ which is less than the Bromus catharticus. About $2.51 \mathrm{~g} / \mathrm{kg}$ calcium content alter the mineral deficiency and low amount causes serious problems in grazing animals. Therefore, minor amount also useful for breast feeding cattle [15]. Highest calcium contents varies from 2000 to $2600 \mathrm{mg} / 100 \mathrm{~g}$, magnesium ranges from 300 to $350 \mathrm{mg} / 100 \mathrm{~g}$, potassium ranges from 1780 to $1850 \mathrm{mg} / 100 \mathrm{~g}$ while the remaining elements were in few amounts (zinc 1 $\mathrm{mg} / 100 \mathrm{~g}$, selenium $1 \mathrm{mg} / 100 \mathrm{~g}$ and copper $0.1 \mathrm{mg} / 100 \mathrm{~g}$ ) were observed and identified 2 cultivars i-e Lombardia and San Pedro. Lombardia cultivar contain larger amount of iron whereas, in San Pedro cultivar calcium, magnesium and sodium contents are in less amounts by Solana et al [16]. Alopecurus myosuroides share $(0.07 \%)$ aluminum contents in pre reproductive stage followed by Phalaris minor with regards to aluminum contents. Highest sodium level were observed in Phalaris minor in all the three growth stages $(0.15 \%, 0.61 \%$ and $0.52 \%)$ and absent in Polypogon fugax, Alopecurus myosuroides and Hordeum murinum. Khan et al [4] also give evidence that in all the examined grasses sodium amount increased in all the advance growth stages, therefore in forage herbaceous grasses very low concentrations of these nutrients are required for its utilization [17]. Copper were observed and present in very low amount in all the examined taxa in variable stages. Thus copper and zinc that is responsible for incrementation of milk in pregnant animals and essential for hair growth [18]. Nitrogen contents share $(13.03 \%)$ in Phalaris minor in pre reproductive stage while Hordeum murinum share $(4.17 \%)$ in reproductive stage in decreasing order. Iron and zinc were 
present in trace amount in all herbaceous grasses, thus higher amount of iron required for ruminants present in forage grasses than the normal requirements 30-60 mg [19]. Zinc availability and its utilization mainly depend on its composition, structure and their association with other mineral [20]. Nutrients that present in low amounts are C, $\mathrm{O}, \mathrm{Si}, \mathrm{P}, \mathrm{S}, \mathrm{Cl}$ and $\mathrm{K}$ in decreasing order from pre reproductive to post reproductive stages. Hence these minerals are required for all metabolic processes and needed for proper growth, function and development [21]. About 40 different elements were reported by different workers and give suggestion that these elements are essential for life system and for the survival of organisms [22]. Minerals monopolize topmost turned in animal nutrition for its manufacturing, biological availability and for good and proper health [23]. Samreen et al [24] also identified 12 nutrients in forage grasses from FR, Darazinda Valley, Pakistan. Khan et al. [25] also documented comparative proximate study of some weedy grasses for potential use as fodder from district Peshawar and represented higher DM contents and low moisture. Thus on the basis of current findings we suggest that all grass species have high potential for their utilization as fodder and forage which provide a baseline to overcome the current shortage of fodder through country as well as globally.

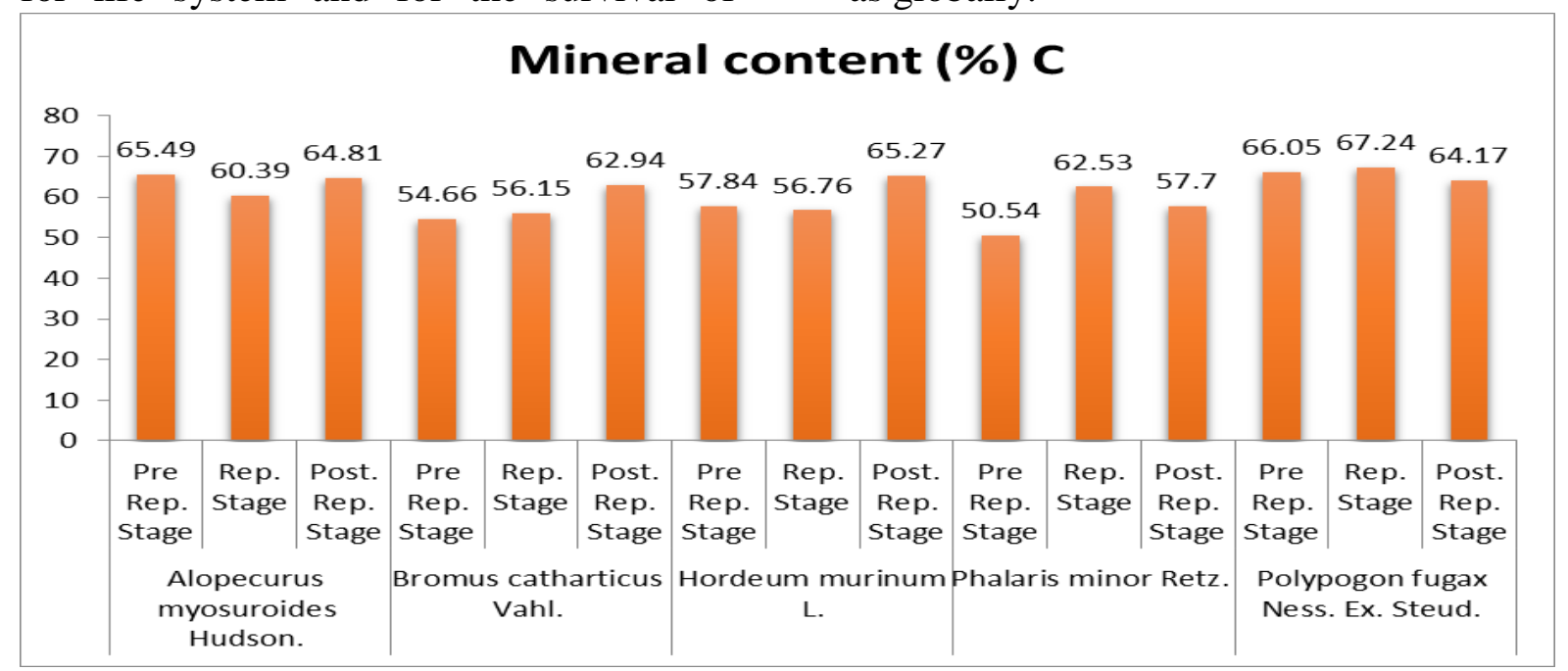

Figure 1. Variation of $\mathrm{C}$ in Five species of Pooideae in three different phenological stages

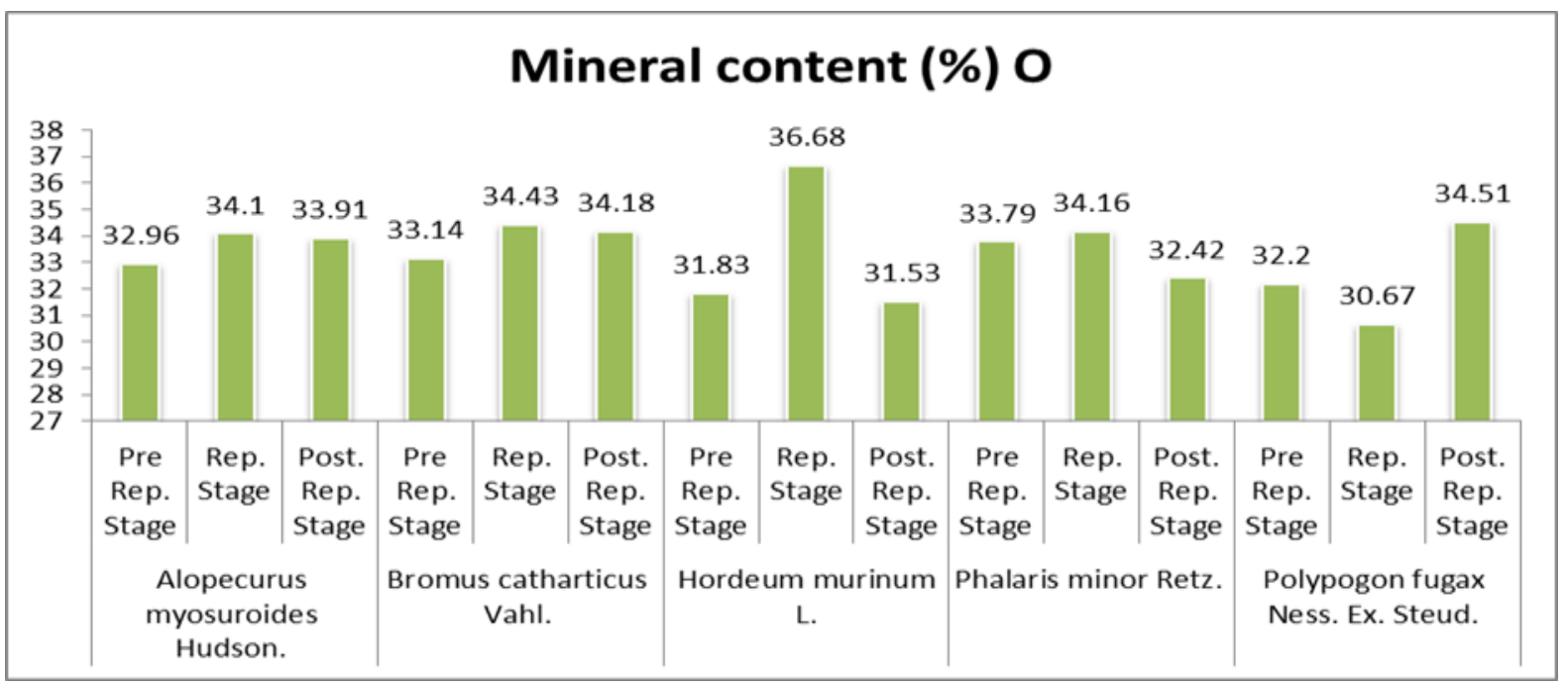

Figure 2. Variation of $\mathrm{O}$ in Five species of Pooideae in three different phenological stages 


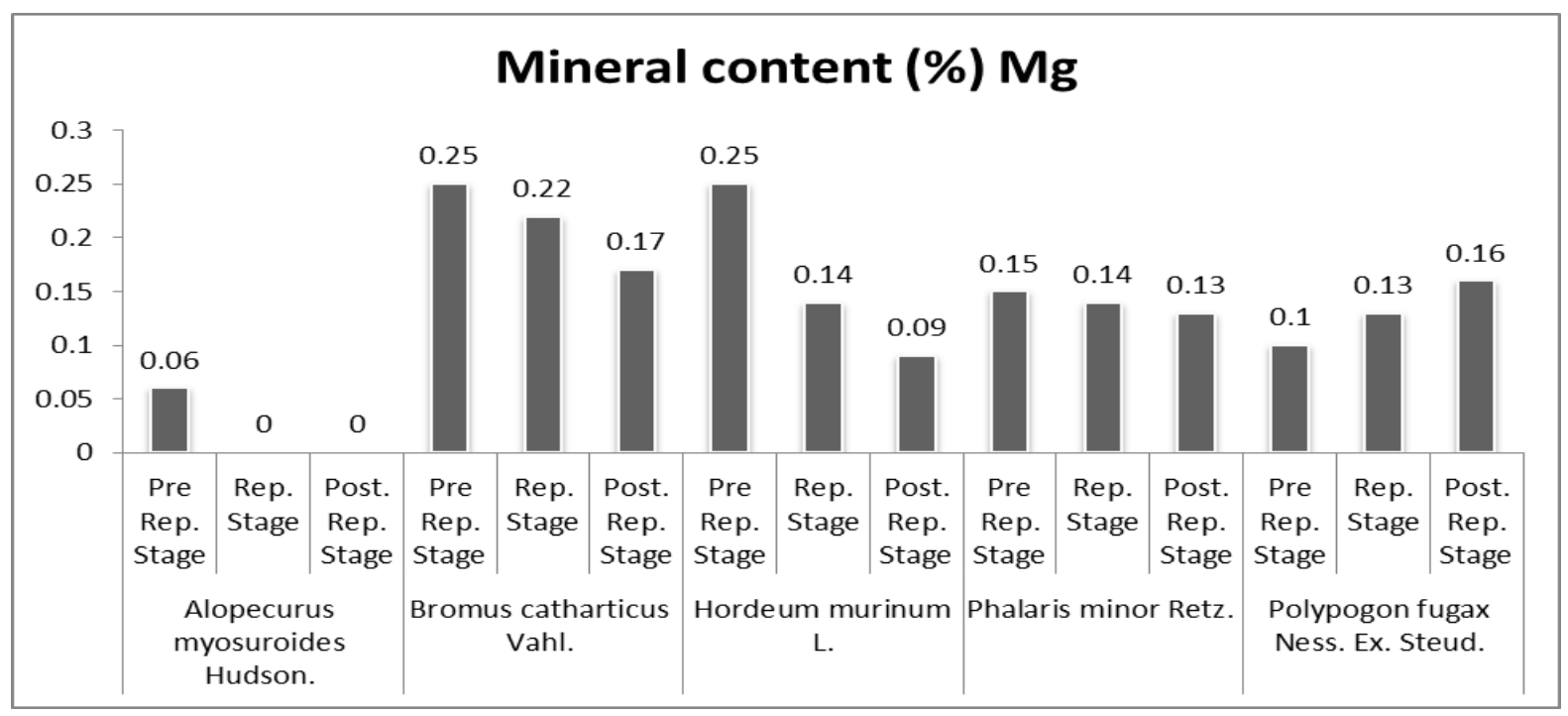

Figure 3. Variation of $\mathrm{Mg}$ in Five species of Pooideae in three different phenological stages

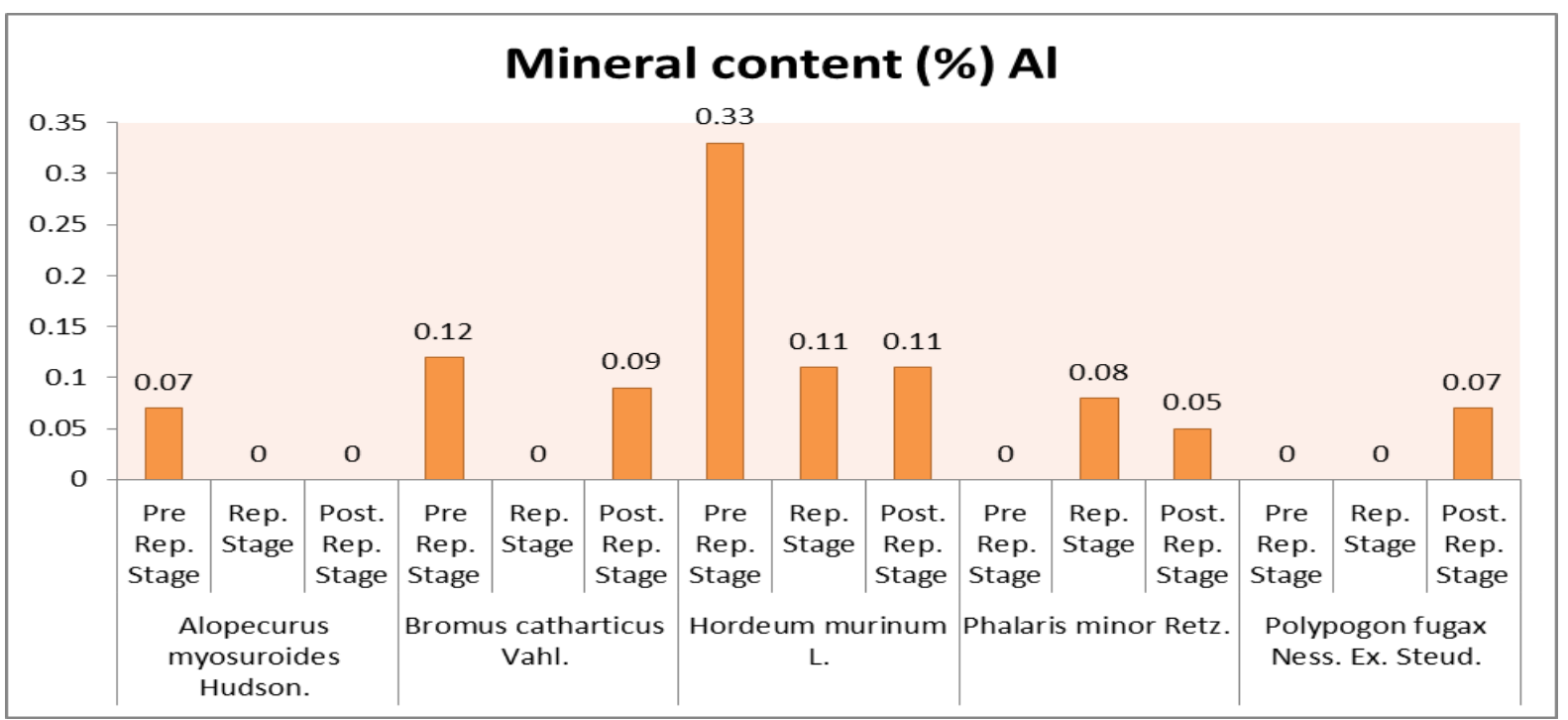

Figure 4. Variation of $\mathrm{Al}$ in Five species of Pooideae in three different phenological stages

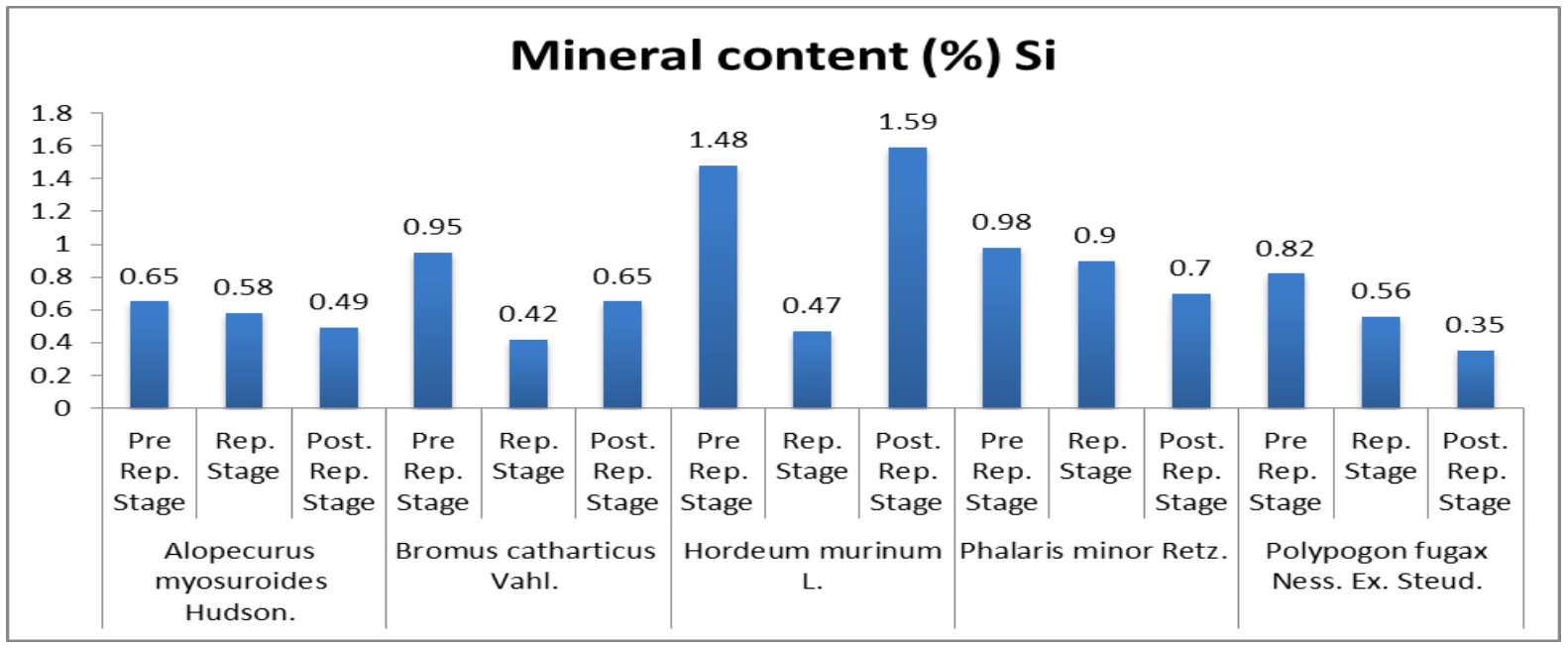

Figure 5. Variation of Si in Five species of Pooideae in three different phenological stages 


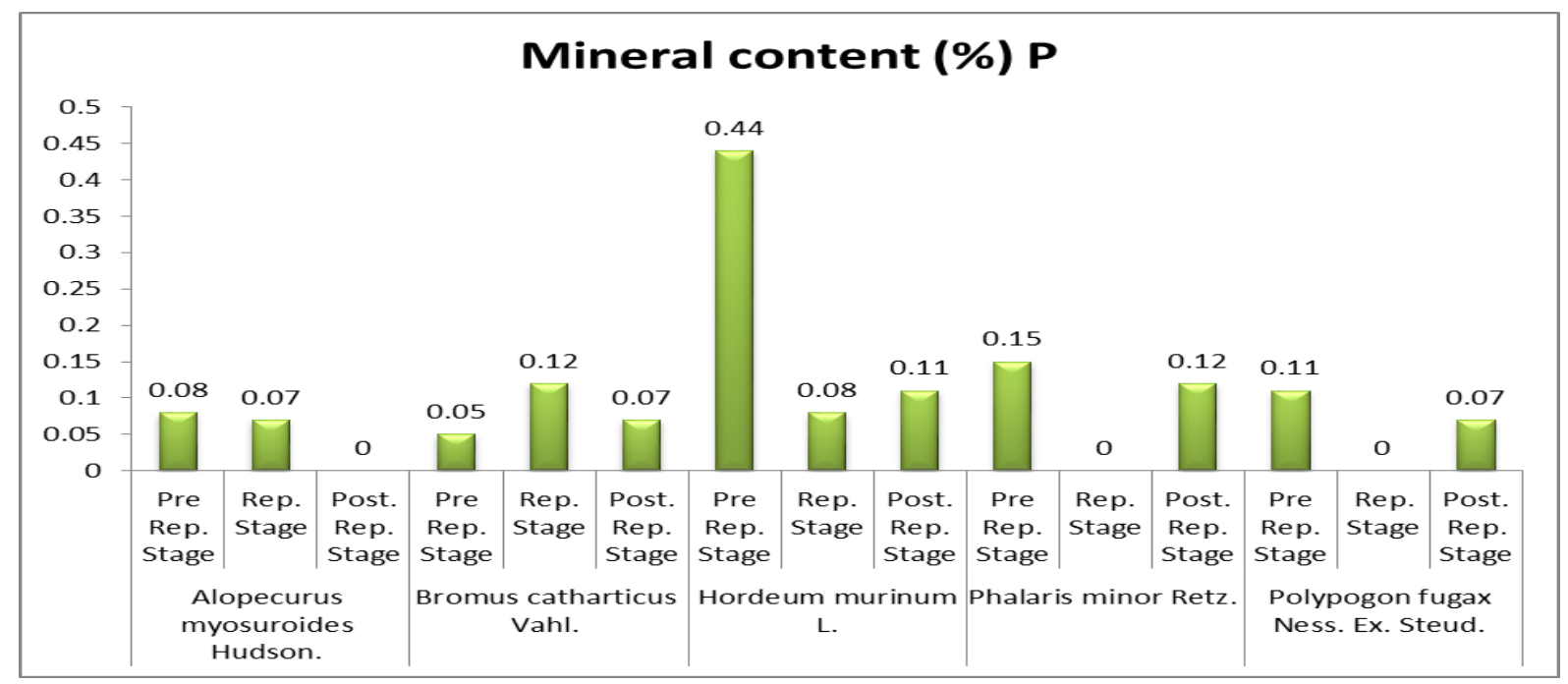

Figure 6. Variation of $\mathbf{P}$ in Five species of Pooideae in three different phenological stages

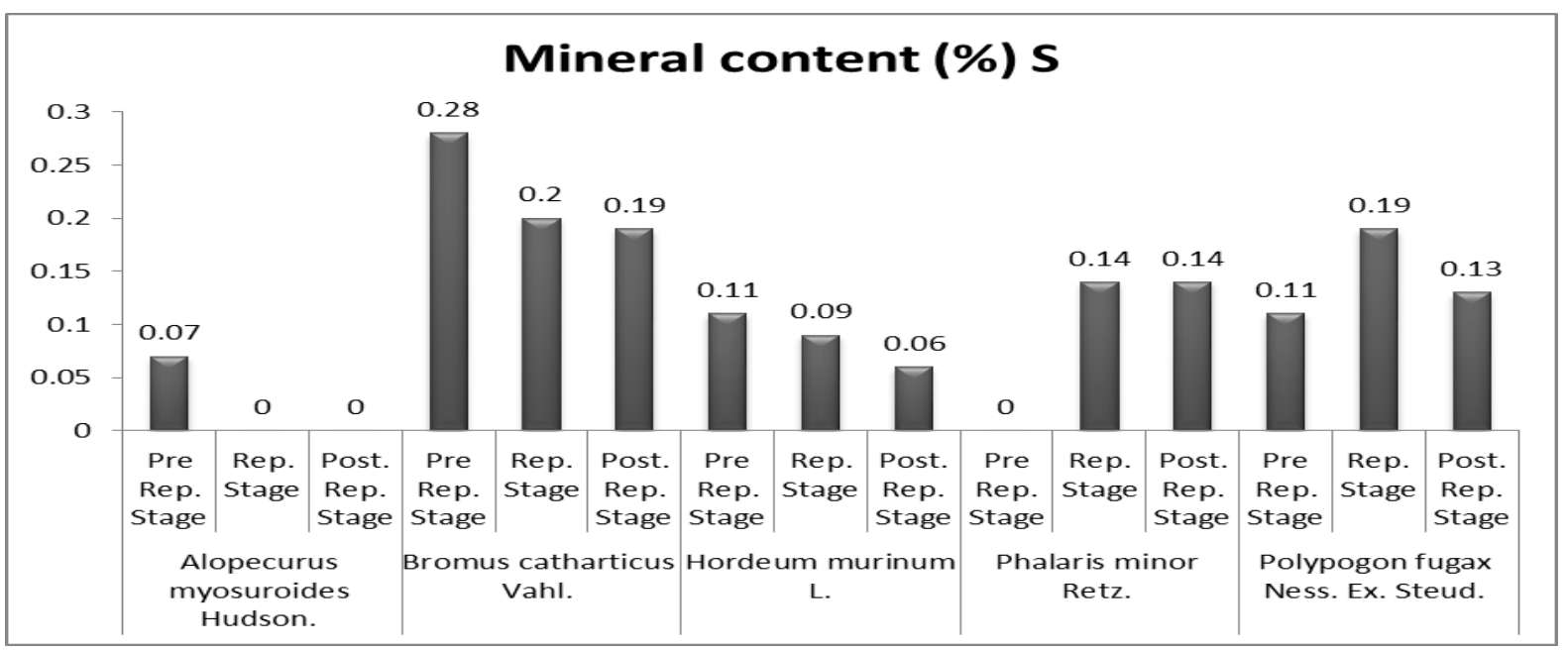

Figure 7. Variation of $S$ in Five species of Pooideae in three different phenological stages

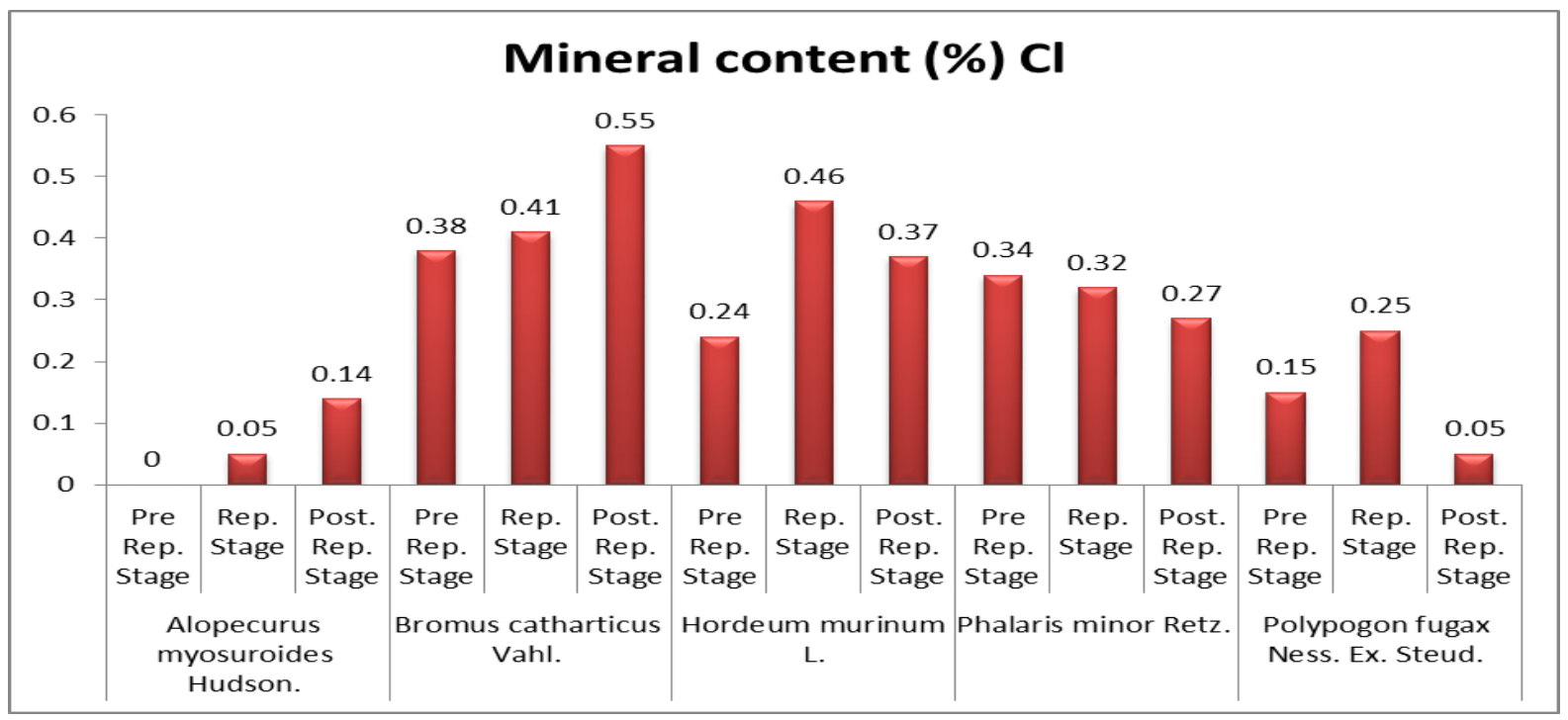

Figure 8. Variation of $\mathrm{Cl}$ in Five species of Pooideae in three different phenological stages 


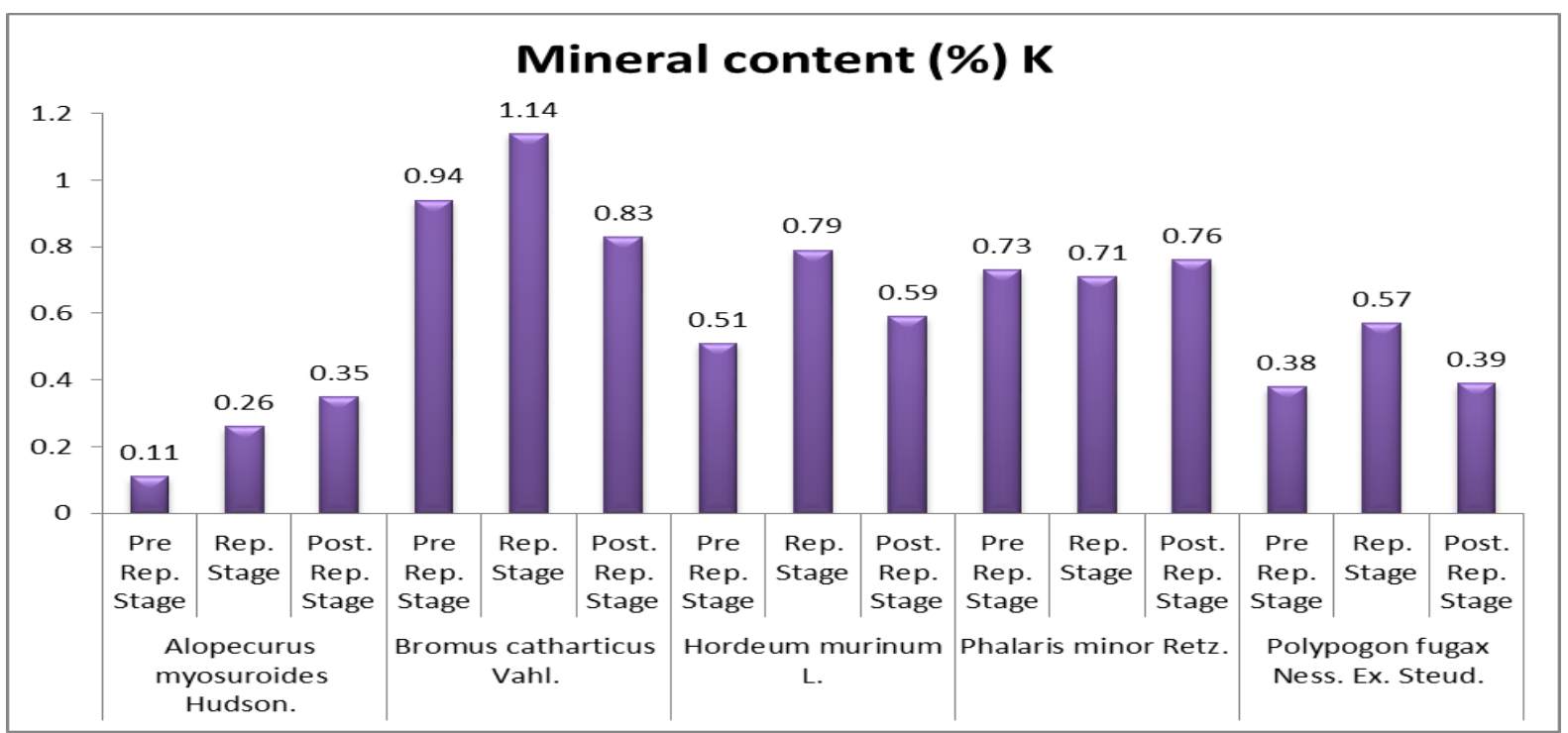

Figure 9. Variation of $K$ in Five species of Pooideae in three different phenological stages

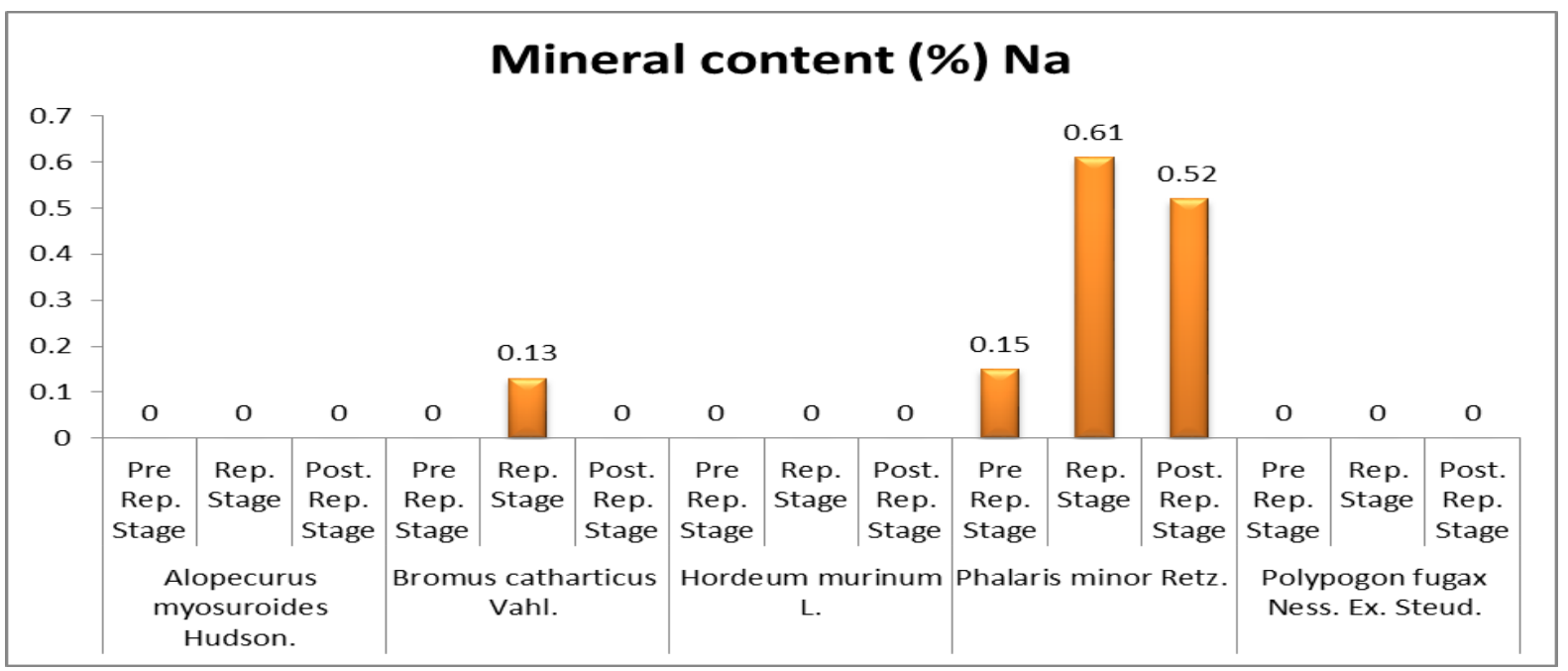

Figure 10. Variation of $\mathrm{Na}$ in Five species of Pooideae in three different phenological stages

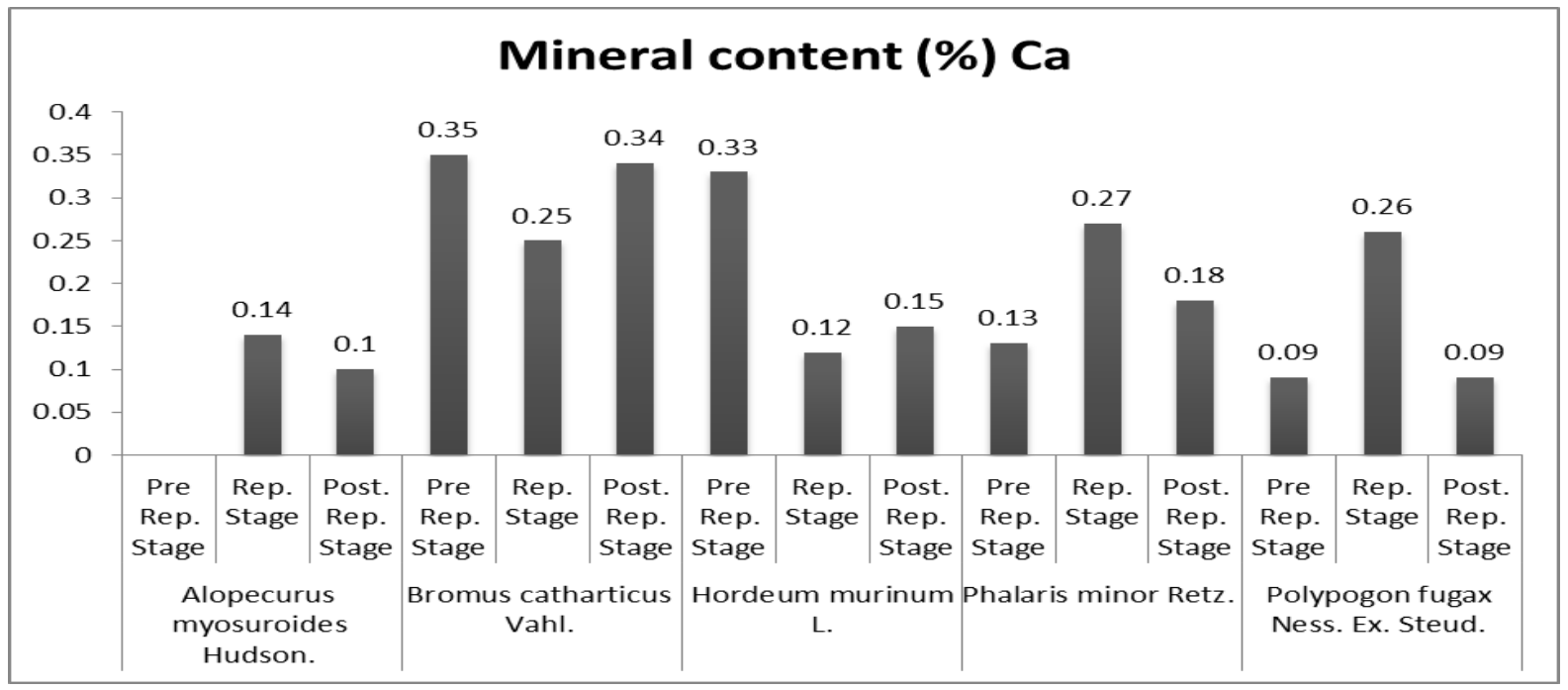

Figure 11. Variation of $\mathrm{Ca}$ in Five species of Pooideae in three different phenological stages 


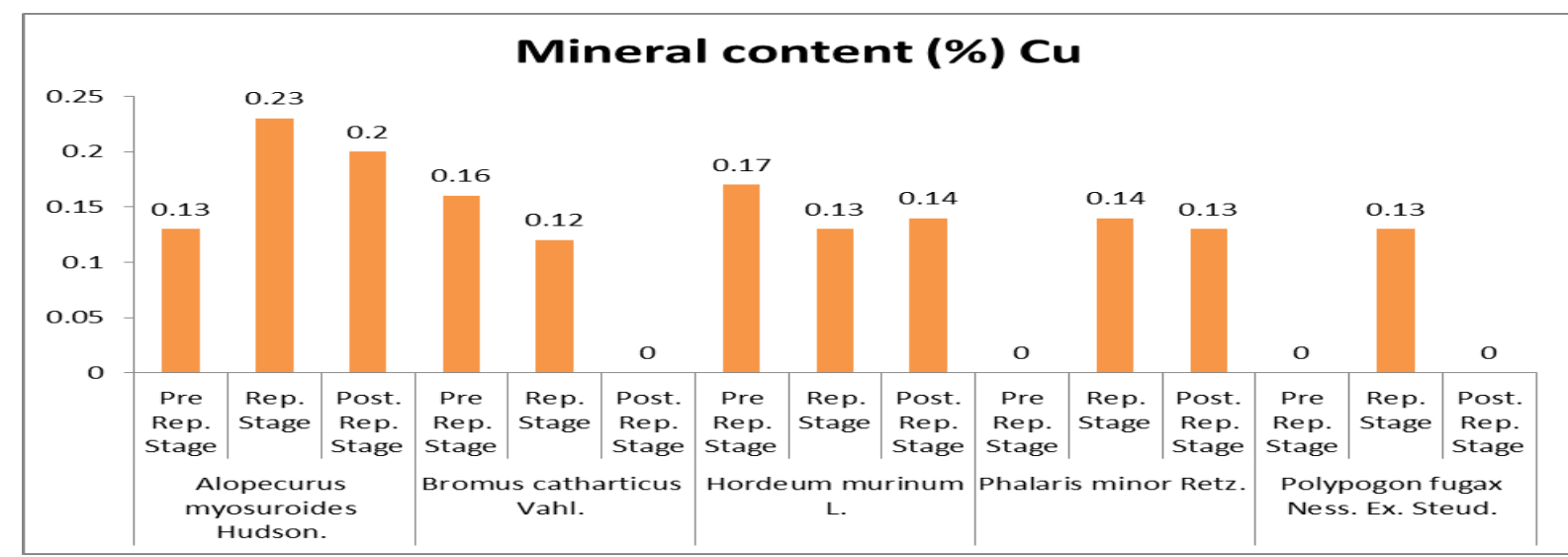

Figure 12. Variation of $\mathrm{Cu}$ in Five species of Pooideae in three different phenological stages

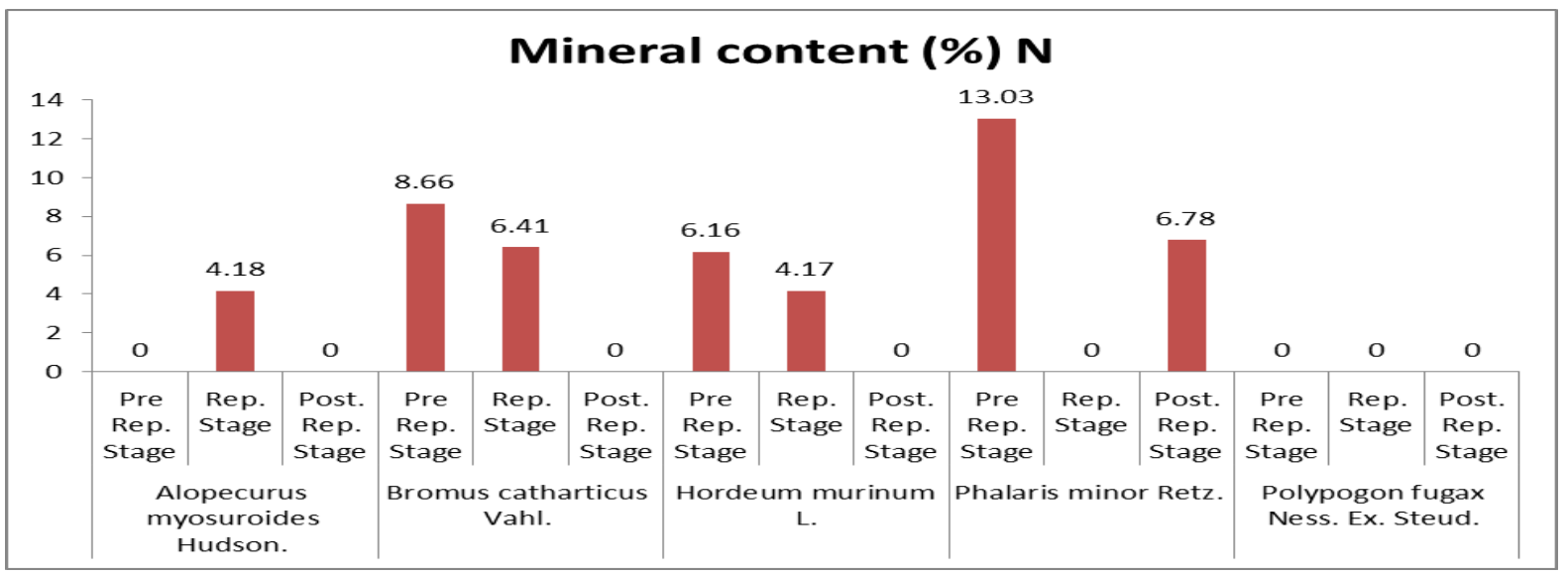

Figure 13. Variation of $\mathbf{N}$ in Five species of Pooideae in three different phenological stages

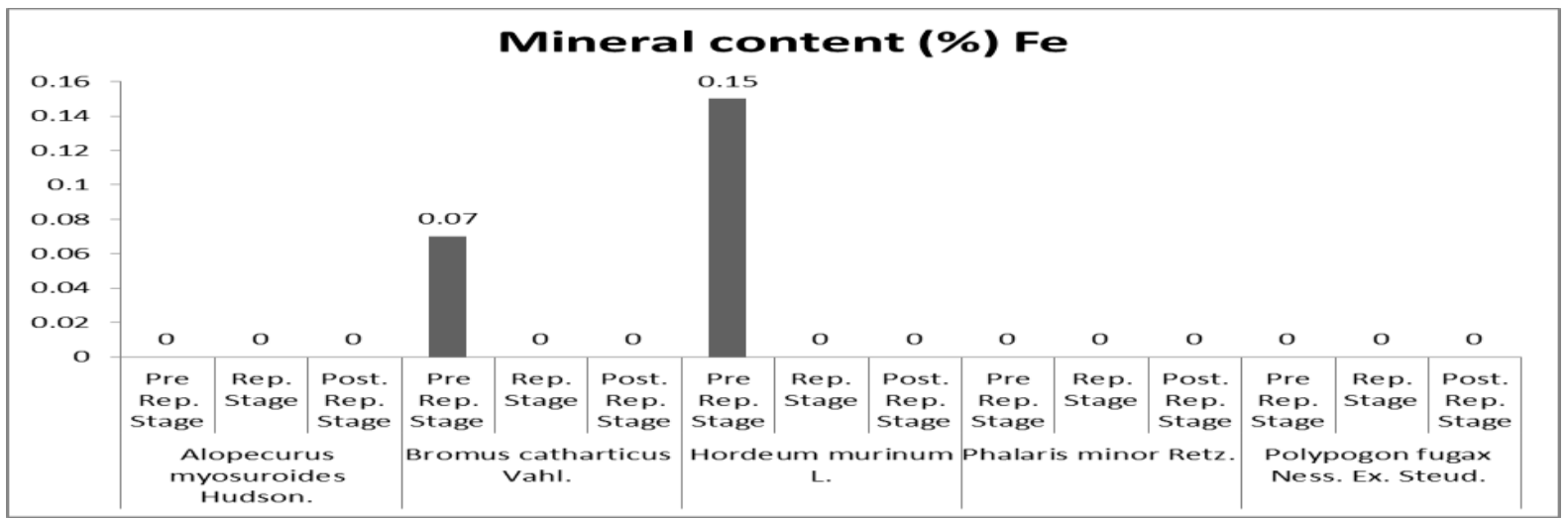

Figure 14. Variation of Fe in Five species of Pooideae in three different phenological stages

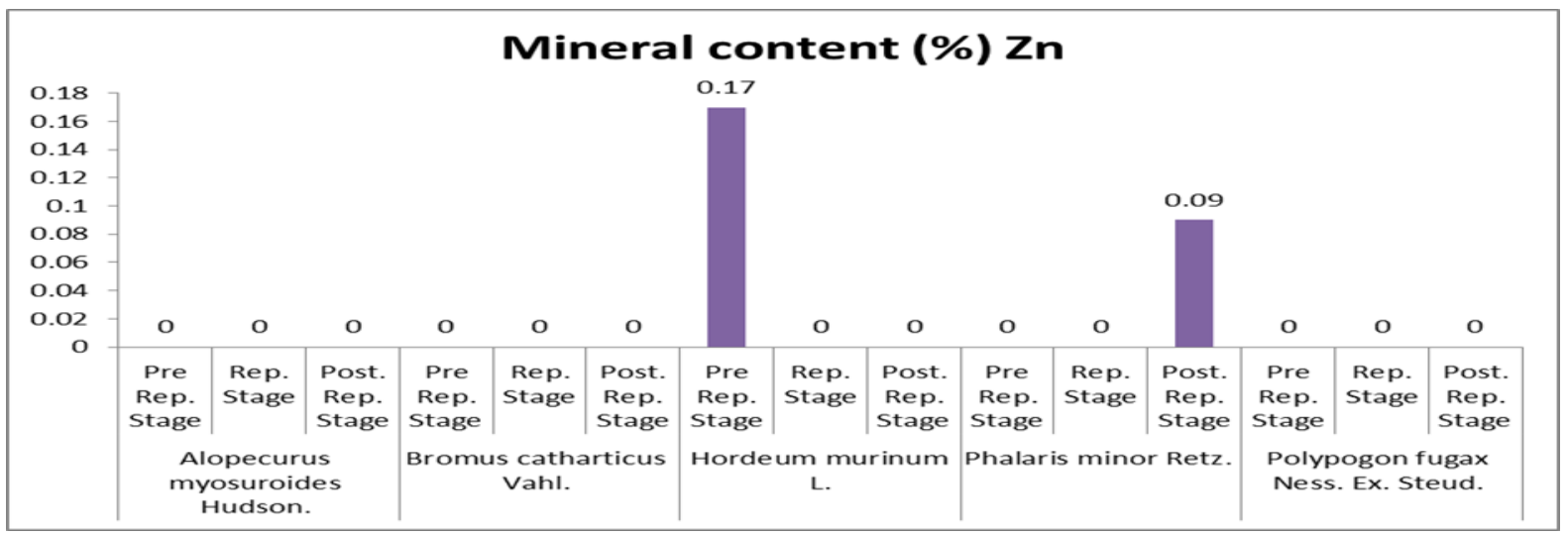

Figure 15. Variation of $\mathrm{Zn}$ in Five species of Pooideae in three different phenological stages 
Table 1. Botanical names, common names and distribution of grasses of sub family Pooideae

\begin{tabular}{|c|c|c|c|c|}
\hline S. No & Botanical Name & Common name & Distribution in Pakistan & Distribution in world \\
\hline $\mathbf{1 .}$ & $\begin{array}{c}\text { Alopecurus myosuroides } \\
\text { Hudson. }\end{array}$ & $\begin{array}{c}\text { Black grass, Slender } \\
\text { meadow foxtail }\end{array}$ & $\begin{array}{c}\text { Baluchistan, Khyber } \\
\text { Pakhtunkhwa \& Kashmir }\end{array}$ & $\begin{array}{c}\text { Europe and temperate Asia; introduced in North America and } \\
\text { other temperate regions }\end{array}$ \\
\hline $\mathbf{2 .}$ & Bromus catharticus Vahl. & Rescue grass & $\begin{array}{c}\text { Punjab \& Khyber } \\
\text { PakhtunKhwa }\end{array}$ & Native to South America, Europe, Australia and North America. \\
\hline $\mathbf{3 .}$ & Hordeum murinum L. & False barley & $\begin{array}{c}\text { Khyber PakhtunKhwa \& } \\
\text { Kashmir }\end{array}$ & Mediterranean region eastwards to Central Asia and China. \\
\hline 4. & Phalaris minor Retz. & $\begin{array}{c}\text { Little seed canary } \\
\text { grass, } \\
\text { Mediterranean } \\
\text { canary grass }\end{array}$ & $\begin{array}{c}\text { Baluchistan, Punjab, } \\
\text { Khyber Pakhtunkhwa \& } \\
\text { Kashmir }\end{array}$ & $\begin{array}{c}\text { Throughout the world, but apparently native only in the } \\
\text { Mediterranean region and eastwards to Baluchistan and the } \\
\text { Northwest Himalayas. }\end{array}$ \\
\hline $\mathbf{5 .}$ & $\begin{array}{c}\text { Polypogon fugax } \text { Ness. Ex. } \\
\text { Steud. }\end{array}$ & $\begin{array}{c}\text { Asia Minor Blue } \\
\text { grass }\end{array}$ & $\begin{array}{c}\text { Baluchistan, Punjab, Khyber } \\
\text { PakhtunKhwa \& Kashmir }\end{array}$ & Iraq eastwards to Burma, mainly in the Himalayas. \\
\hline
\end{tabular}

\section{Table 2. Mean mineral content of fodder species of Sub family Pooideae}

\begin{tabular}{|c|c|c|c|c|c|c|c|c|c|c|c|c|c|c|c|c|c|}
\hline $\begin{array}{c}\text { S. } \\
\text { No }\end{array}$ & Botanical Name & Phenological stages & \multicolumn{15}{|c|}{ Mineral content $(\%)$} \\
\hline & & & $\mathbf{C}$ & $\mathbf{O}$ & Mg & Al & $\mathbf{S i}$ & $\mathbf{P}$ & $\mathbf{S}$ & $\mathbf{C l}$ & $\mathbf{K}$ & $\mathbf{N a}$ & $\mathbf{C a}$ & $\mathbf{C u}$ & $\mathbf{N}$ & $\mathbf{F e}$ & Zn \\
\hline \multirow{3}{*}{1.} & \multirow{3}{*}{$\begin{array}{c}\text { Alopecurus } \\
\text { myosuroides Hudson. }\end{array}$} & Pre reproductive stage & 65.49 & 32.96 & 0.06 & 0.07 & 0.65 & 0.08 & 0.07 & - & 0.11 & - & & 0.13 & - & - & - \\
\hline & & Reproductive stage & 60.39 & 34.10 & - & - & 0.58 & 0.07 & - & 0.05 & 0.26 & - & 0.14 & 0.23 & 4.18 & - & - \\
\hline & & Post reproductive stage & 64.81 & 33.91 & - & - & 0.49 & - & - & 0.14 & 0.35 & - & 0.10 & 0.20 & - & - & - \\
\hline \multirow{3}{*}{2.} & \multirow{3}{*}{$\begin{array}{c}\text { Bromus catharticus } \\
\text { Vahl. }\end{array}$} & Pre reproductive stage & 54.66 & 33.14 & 0.25 & 0.12 & 0.95 & 0.05 & 0.28 & 0.38 & 0.94 & - & 0.35 & 0.16 & 8.66 & 0.07 & - \\
\hline & & Reproductive stage & 56.15 & 34.43 & 0.22 & - & 0.42 & 0.12 & 0.20 & 0.41 & 1.14 & 0.13 & 0.25 & 0.12 & 6.41 & - & - \\
\hline & & Post reproductive stage & 62.94 & 34.18 & 0.17 & 0.09 & 0.65 & 0.07 & 0.19 & 0.55 & 0.83 & - & 0.34 & - & - & - & - \\
\hline \multirow{3}{*}{3.} & \multirow{3}{*}{ Hordeum murinum L. } & Pre reproductive stage & 57.84 & 31.83 & 0.25 & 0.33 & 1.48 & 0.44 & 0.11 & 0.24 & 0.51 & - & 0.33 & 0.17 & 6.16 & 0.15 & 0.17 \\
\hline & & Reproductive stage & 56.76 & 36.68 & 0.14 & 0.11 & 0.47 & 0.08 & 0.09 & 0.46 & 0.79 & - & 0.12 & 0.13 & 4.17 & - & - \\
\hline & & Post reproductive stage & 65.27 & 31.53 & 0.09 & 0.11 & 1.59 & 0.11 & 0.06 & 0.37 & 0.59 & - & 0.15 & 0.14 & - & - & - \\
\hline \multirow{3}{*}{4.} & \multirow{2}{*}{ Phalaris minor Retz. } & Pre reproductive stage & 50.54 & 33.79 & 0.15 & - & 0.98 & 0.15 & - & 0.34 & 0.73 & 0.15 & 0.13 & - & 13.03 & - & - \\
\hline & & Reproductive stage & 62.53 & 34.16 & 0.14 & 0.08 & 0.90 & - & 0.14 & 0.32 & 0.71 & 0.61 & 0.27 & 0.14 & - & - & - \\
\hline & & Post reproductive stage & 57.70 & 32.42 & 0.13 & 0.05 & 0.70 & 0.12 & 0.14 & 0.27 & 0.76 & 0.52 & 0.18 & 0.13 & 6.78 & - & 0.09 \\
\hline \multirow{3}{*}{5.} & \multirow{3}{*}{$\begin{array}{l}\text { Polypogon fugax } \\
\text { Ness. Ex. Steud. }\end{array}$} & Pre reproductive stage & 66.05 & 32.20 & 0.10 & - & 0.82 & 0.11 & 0.11 & 0.15 & 0.38 & - & 0.09 & - & - & - & - \\
\hline & & Reproductive stage & 67.24 & 30.67 & 0.13 & - & 0.56 & - & 0.19 & 0.25 & 0.57 & - & 0.26 & 0.13 & - & - & - \\
\hline & & Post reproductive stage & 64.17 & 34.51 & 0.16 & 0.07 & 0.35 & 0.07 & 0.13 & 0.05 & 0.39 & - & 0.09 & - & - & - & - \\
\hline
\end{tabular}




\section{Conclusion}

The current study concluded that all the examined species with regards to mineral composition are best source of fodder for grazing livestock. Information on wild grasses regarding their nutritional value, cell wall composition, secondary metabolites, antioxidant activities, antimicrobial activities and their biological significance must be useful for future use. Therefore, this work highlighted the mineral status, composition and potentiality of fodder species.

\section{Authors' contributions}

Conceived and designed the experiments: SM Shah \& MN Khan, Performed the experiments: MN Khan \& S Ali, Analyzed the data: MN Khan, H Akram \& IU Haq, Contributed materials/ analysis/ tools: $\mathrm{MN}$ Khan, FU Jan \& SM Hanif, Wrote the paper: MN Khan \& M Adnan, Proof reading: AN Siddique.

\section{References}

1. Chughtai SM and Shah (1989). Illustrated checklist of the plants of the Peshawar University

2. Cope TA (1982). Poaceae In Flora of Pakistan (Eds.): Nasir E \& Ali SI 143: 40-678. Karachi.

3. Smith JPJ (2005). Agrostology; An Introduction to the Systematics of Grasses. Botanical Studies 10.

4. Khan M, Hussain F \& Musharaf S (2013). Macro-mineral contents in ten species at three phenological stages in Tehsil Takhte- Nasrati, District Karak, Pakistan. African J of Agric Res 8: 65475-5484.

5. Pandey M, Abidi AB, Singh S \& Singh RP (2006). Nutritional Evaluation of Leafy Vegetable Paratha. J Hum Ecol 19 (2): 155-156.

6. Mehmood A, Shah AH, Khan SM, Rehman IU \& Ahmad H (2017). Floristic List and Indigenous Uses of Poaceae Family in District Tor Ghar, Khyber Pakhtunkhwa, Pakistan. J Appl Environ Biol Sci 7(6): 169-177.

7. Khan S, Anwar K, Kalim K, Saeed A, Shah SZ, Ahmad Z, Ikram HM, Khan
S \& Ullah S (2014). Nutritional Evaluation of Some Top Fodder Tree Leaves and Shrubs of District Dir (Lower), Pakistan as a quality livestock feed. Inter J Curr Microbiol Appl Sci 3(5): 941-947.

8. Khan MA \& Ullah I (1984). Food and nutrition situation in Pakistan. Progressive farming 4(5): 1-5.

9. Hannah MAC \& Krishnakumari S (2015). Analysis of Mineral Elements, Proximate and Nutritive value in Citrullus vulgaris Schrad. (Watermelon) seed extracts. The Pharma Innov J 4(8): 07-11.

10. Nisar M, Tariq SA \& Ullah I (2009). Nutritional levels of Indigofera gerdiana Wall and Crataegus songrica. K Koch Pak J Bot 41(3): 1359-1361.

11. Anonymous (2006). Economic Survey. Government of Pakistan, Finance Division, Islamabad, Pakistan.

12. Cope TA (1982). Poaceae in Flora of Pakistan (Eds.): Nasir E \& Ali SI 143: 40-678. Karachi.

13. Stewart RR (1972). An annotated catalogue of the vascular plants of West Pakistan and Kashmir Fakhri printing press Karachi 1-1064.

14. Soetan KO, Olaiya CO \& Oyewole OE (2010). The importance of mineral elements for humans, domestic animals and plants: A review. Afr J Food Sci 4(5): 200-222.

15. Ahmad K, Khan ZI, Shaheen M, Mirzaei F, Hussain A, Arshad F, Mehmood T, \& Bibi Z (2013). Exploration of concentration of two macro-minerals in different wild forages in relation to nutrient requirements of livestock Agri Sci 4(7): 340-344.

16. Solana MAV, Garcia VYM, Valencia AT, Arenas GG, Pacheco JS, Romero JJA \& Campos ES (2015). Nutritional content and elemental and phytochemical analyses of Moringa oleifera grown in Mexico. J of Chem 19. 
17. Mirzaei F (2012). Minerals profile of forages for grazing ruminants in Pakistan Open Journal of Animal Sciences 2(3): 133-141.

18. Valkovic VV (1975). Trace Element Analysis. London: Taylor and Francis, pp 5-83.

19. McDowell LR (1992). Minerals in animal and human nutrition. Academic Press, San Diego.

20. Reuter DJ \& Robinson JB (1997). Plant analysis. An interpretation manual. 2nd Edition, CSIRO Publishing, Melbourne.

21. Masters DG, Purser DB, Yu SX, et al. (1993). Mineral nutrition of grazing sheep in northern China. I. Macrominerals in pasture feed supplements and sheep. Asian-Australian J of Anim Sci 6(1): 99-105.

22. Armah Y, Nyarko S, Akaho BJB, Kyere EHK, Osae AWK, Boachie KO
\& Osae EK (2001). Activation analysis of some essential elements in five medicinal plants used in Ghana. $J$ Radioanalytical Nuclear Chem 250(1): 173-176.

23. McDonald P, Edwards RA, Greenhalgh JFD \& Morgan CA. (2009). Animal Nutrition. $6^{\text {th }}$ edition. Pearson Education Ltd.

24. Samreen U, Ibrar M, Badshah L \& Ullah B (2016). Nutritional and Elemental Analysis of Some Selected Fodder Plants of Darazinda FRDI Khan, Pakistan. Adv Plants Agric Res 4(1): 00127.

25. Khan R, Khan MN, Ullah H, Basit A, Razzaq A, Ahmad M \& Ozdemir FA. (2018). A comparative assessment of proximate and elemental composition six weedy grasses for their potential use as fodder. Progress in Nutri 20(1S): 182-190. 